\title{
The Direction Development Research of Computer Education Technology
}

\author{
Lan Zhou ${ }^{1, a}$ \\ ${ }^{1}$ Liuzhou Railway Vocational Technical College, China \\ a2454768597@qq.com
}

\begin{abstract}
Key words: Computer, Education technology, Development direction, Research
Abstract.The wide application of computer is social development and technological progress. The wide application of computer has brought great changes to the society; it is convenient for the social life of human being. With the development of social economy, the improvement of the computer technology is continuous. The application of computer in education industry is also put forward the new requirements of development. People practices in computer education application have been 50 years.The process of computer teaching has been applied to the education activity in countries all over the world.The theoretical basis of computer education application is cognitive constructivism from the initial development to today's behaviorism. In order to reaching the goal of computer accommodation with education,People must correctly grasp the relationship between human and machine and the relationship between technology and education.On the basis of that people must constantly improve the teaching mode to make computer education technology development in the healthy and orderly direction.
\end{abstract}

\section{Introduction}

With the continuous development of social economy, the progress of science and technology, society gradually in the perspective of information, diversified development, the computer education of innovation activities, as a kind of education industry, its application development model has a great promotion on the effectiveness of education. That can be seen from the information collected at home and abroad, the current computer education has developed into a new stage, and teaching achievements in technology and theory has obvious improvement [1]. So, fully understand the main characteristics of this stage computer education and the development trend of computer education could provide theoretical basis for the general computer education workers, to our country the establishment of the development of computer education goal and the perfection of related policy has important guiding significance.

Constructivism emphasizes, the computer multimedia network teaching should take students as the center, change traditional force-feeding teaching methods for students' autonomous learning, let the students from passive to absorb the information into active knowledge explorer, not only can help students better master knowledge, can also fully the students' interest in learning. In the actual process of computer multimedia network teaching, teachers should constantly improve the teaching pattern, involving the new teaching method, help students better learning task, also realize own knowledge quality improvement [2].

\section{The current situation of computer education and the actual effect}

Since the 1980 s, some schools in our country gradually turn the computer with the combination of education and effective, has developed some computer teaching software, fast development, the rich content, is can't be matched by other teaching hardware facilities, including "computer multimedia auxiliary teaching management", "computer standardized tests", etc [3]. The computer multimedia teaching can improve classroom atmosphere, improve the students' interest in learning, help students to learn effectively, in today's society, computer multimedia teaching, network teaching mode) has emerged, not only break the time and distance barriers, under the condition of the cost is relatively low implement one-to-one teaching. In the process of network teaching, students can choose them according to their own conditions of interest courses, can learn more 
knowledge, more comprehensive increase his knowledge.

Because people expect of computer multimedia teaching and optimistic attitude is too high, in the process of practical teaching in some not too optimistic negative events, so in the $1980 \mathrm{~s}$, some scholars and experts in the United States began to evaluate the computer multimedia teaching [3]. The famous American education technology experts in domestic gold computer multimedia teaching practice research results show that: "in most cases, the traditional education model and the computer multimedia teaching mode is no significant difference, so we have to admit that the computer multimedia teaching mode in the school curriculum in the United States the influence of the very few, even have no effect." The role of computer multimedia teaching in education are so small, is that people can understand. In some scholar's point of view, the computer network teaching will have some negative effect to the student, such as network can let students come into contact with a lot of bad information, take student's energy [4]. The supervision of the network teaching, leave the teacher, the student cannot very good arrangement study time, and so on a series of problems.

Under normal development (i.e., correct use of computer network technology with the perfect teaching software), the computer multimedia network technology has a great potential application in the education industry will be advantage. But the reality is that computer teaching did not achieve the desired objectives, the study found that affected by the factors with the device itself, the influence of main factors such as students, teachers, teaching the influence of such factors as hardware, software, computer network technology are not perfectly combined with education, there is no right to use this technology, popular said is that teachers and students use computers for normal teaching activities [4]. In the actual teaching process, if the teacher just to teach book knowledge with computer network technology, it greatly reduces the computer multimedia network technology in the role of teaching.

The application of computer education management. Computer teaching in order to have a very good effect will be to communicate with the teacher, teachers teaching program of our whole work, for unified management of the students' learning is indispensable, to manage the whole teaching process is the need to measure the results of students' learning, and to the management of the daily work of the class [5]. In the classroom, the work is done by the teacher in charge of, these things is very tedious, also to a large extent affected the teacher of the students can understand each other more communication and counseling, also affected the teacher develop its creative side [3]. Many computer software can actually support side impact on the computer management of the whole teaching system, we also want to see on the management of teaching, computer integrated system can calculate and test a variety of software, can also in the management of time and space for teacher to help more students to study.

The application of computer remote education. Computer education cannot be separated from the remote education, modern distance education is used in communication technology based on the role of the computer and network technology, between the computer and network widely distributed, is the comprehensive embodiment of the function of computer is the ability to make people have the opportunity of remote education widely [6]. Throughout the world have now, to the attention of the education have largely around the world, within the scope of the modern distance education is a project by a lot of attention, many of the personnel and education research in scientific and technological innovation talents are the remote education as the key research object. And is the difference between the traditional TV teaching [6]. Distance education is now have real time to a program in communication, students can according to computer generated images and sound to a variety of information transformation, each student in any place at any time to be able to learn all kinds of oneself want to learn the knowledge, and according to own actual situation to determine the learning progress.

\section{The development trend of computer education}

Since the $1970 \mathrm{~s}$, great changes have taken place in education pattern from country to country, most countries do not exist the phenomenon of illiteracy, teaching also gradually heavier amount to 
pay attention to the quality of teaching [7]. With the continuous development of computer network technology, the coming of information society, people have the big increase in the total knowledge, knowledge update speed accelerating, makes the education industry is facing severe challenge. So the relevant departments should pay attention to the teaching of computer, update course structures and teaching content, improve the teachers' computer knowledge accomplishment, to realize the perfect combination of computer and education.

For the organic combination of computer multimedia and network in education industry role is to everyone, leading the trends of education. Since computer multimedia technology and network, the original can be transformed into static document is dynamic execution of code, to now can offer computer network users include text, graphics, animation, and sounds of multimedia information, realizes the technology improved [7]. With the continuous development of computer multimedia data compression and reduction technology, in recent years, the network technology company has developed two multi-function teaching software, to achieve voice compression and reduction has produced a good effec.

Computer education technology is a process of learning and learning resources to carry on the design, development, utilization, management and evaluation of theory and practice [8]. Due to computer education application, of course, is a practical subject, only mastered the basic theory is not enough, also need to apply to the practice, so in computer practice course, teachers should be appropriately increased applied type, design and development of new practice content, give full play to students' practice ability and innovation ability.

The student-centered learning environment. To produce students with computer control this can find a lot of new information environment in which to learn, this is our in the process of the development of computer technology can see a big trend. Like to study in such an environment, the students will be able to quickly grasp the learning methods, and in the field of exploring a correct assumption and the experimental results [8]. This pattern is place the self-knowledge of the ability of students in the first place, fully developing the students' ability of complex thinking. The teachers also use information technology to for students to organize and explain some common teaching methods is difficult to convey knowledge. Convenience brought by the information technology is men who can help computer learning now get a lot of useful new information generated by the society.

Computer the functional resume counseling.According to education scientists predict that in the coming era of intelligent robot, in the process of computer teaching have intelligent learning applications. The students can get from these smart mentee academic problems of professional solutions, students can learn different from their professional experts in scientific thinking. These programs are to be able to help our students to realize the system [9].

The progress of information technology, and in the use of computer education, is used to make our education changing up. These changes are not a day for two days, our experts from the ministry of education put the computer as an independent course in compulsory education, and physical and chemical properties of the same science courses [9]. Learn computer to achieve the purpose is to be able to produce supplementary role to other disciplines.

\section{Summary}

Due to the wide application of computer multimedia network teaching, make students earlier entered the information highway, realize the application of multimedia computer education and network. Computer education application series curriculum system design based on education technology professional curriculum system reform for reference, reflects the basic quality, strong ability of personnel training direction. Famous American educator Dr Allen said in his report: "the modern computers have become the target of education tools rather than education." Therefore, we should renew the idea, network education will become universal education in the 21st century the dominant way, will change the way the life of people study and work. In the future development, we should adapt to the innovative education situation need to improve the computer multimedia network teaching mode, to achieve better teaching results, improve the level of computer education. 


\section{References}

[1] G.D.Liu, The position and the role of the computer in the school teaching, Journal of comparative education research, 1997, pp11-16.

[2] Y.T.Jin. Thinking about network education era continues education, Journal of teaching, 2002, vol.2, pp.34-37.

[3] Sh.H. Feng, Use of network technology to develop continuing education study, Journal of plain university, 2003, vol. 32, pp.44-46.

[4] X.H. Yang, Education technology undergraduate matrix structure curriculum system reform plan, Journal of electrochemical education research, 2000, vol.2, pp.56-62.

[5] G.H. Chen,The modern education technology research, Beijing normal university, 1997, vol.42, pp. 76-81.

[6] Ch.L. Chen, The application of computer in teaching, Beijing guangming daily press,2008, vol.8, pp.91-94.

[7] H.K. Zhong, At the beginning of the progress of science and technology education on international, Beijing: science press, 1999, pp.13-17.

[8] X.M.Sang and Q.W. Zhang, Enter the information age of learning theory and practice, Beijing: central radio and television university press, 2000, vol.6, pp.3-7.

[9] Q.Q. Zhong and H.Zhang, World trends of curriculum reform, Beijing: Beijing normal university press, 2012, vol.11, pp.8-14. 